\title{
Synergistic Anticancer Activity of Combined Use of Caffeic Acid with Paclitaxel Enhances Apoptosis of Non- Small-Cell Lung Cancer H1299 Cells in Vivo and in Vitro
}

Jie Min Hua Shen Wang Xi Qing Wang Liang Yin Yufeng Zhang Yue Yu Qian Yang Zhinong Wang

Department of Cardiothoracic Surgery, Changzheng Hospital, Second Military Medical University, Shanghai, China

\section{Key Words}

Lung cancer $\bullet$ Caffeic acid $\bullet$ MAPK signaling $\bullet$ Paclitaxel $\bullet$ Xenograft

\begin{abstract}
Background/Aims: Caffeic acid (CA) is known to possess multiple biological activities including anti-cancer activities. However, the molecular mechanisms underlying these activities in nonsmall-cell lung cancer (NSCLC) cells are not fully understood. We attempted to clarify whether CA could enhance paclitaxel (PTX)-induced cytotoxicity in $\mathrm{H} 1299$ cells. Methods: First, we tested the cytotoxic effects in both H1299 cells and normal human Bease-2b cells by cell proliferation experiments. Next, we use Annexin V/propidium iodide apoptosis analysis and flow cytometric analysis to investigate apoptosis and cell cycle arrest under the treatments mentioned above. To further pinpoint changes in apoptosis, we tested the caspase-associated apoptotic pathway, which involves the activities of caspase-3 and caspase-9. Moreover, apoptosis-related proteins and MAPK pathway proteins were examined by western blot. An H1299 xenograft nude mice model was used to further evaluate the tumor-suppressing effects of CA and PTX in vivo. Results: Combination treatment with low-dose CA and PTX decreased the proliferation of NSCLC H1299 cells but not normal Beas-2b cells. Flow cytometry showed that $\mathrm{H} 1299$ cells were arrested in the sub-G1 phase and apoptosis was significantly increased in $\mathrm{H} 1299$ cells after CA treatment. Caspase-3 and caspase-9 activities were both increased after CA treatment. Furthermore, CA increased the PTX-induced activation of Bax, Bid, and downstream cleaved PARP, and phosphorylation of extracellular signal regulated kinase $1 / 2$ and c-Jun NH2-terminal protein kinase1/2. An in vivo tumor-suppression assay demonstrated that CA and PTX combined treatment exerted a more effective suppressive effect on tumor

J. Min, H. Shen and W. Xi contributed equally to this work.

\begin{tabular}{ll}
\hline Zhi-nong Wang & Department of Cardiothoracic Surgery, Changzheng Hospital, Second Military Medical University \\
and Qian Yang & Shanghai, 20003 (China) \\
& Tel. +8621 $81885901,+862181885906$, E-Mail wangzn007@smmu.edu.cn, yangqian@smmu.edu.cn
\end{tabular}
\end{abstract}




\section{Cellular Physiology Cell Physiol Biochem 2018;48:1433-1442 \begin{tabular}{l|l} 
DOI: 10.1159/000492253 & $\begin{array}{l}\text { O 2018 The Author(s). Published by S. Karger AG, Basel } \\
\text { www.karger.com/cpb }\end{array}$
\end{tabular} \\ Min et al.: Anticancer Activity of Caffeic Acid with Paclitaxel in H1299 Cells}

growth in $\mathrm{H} 1299$ xenografts without causing significant adverse effects. Conclusions: Our results indicated that CA inhibited NSCLC H1299 cell growth by inducing apoptosis and CA and PTX combined produced a synergistic anti-cancer effect in $\mathrm{H} 1299$ cells.

(C) 2018 The Author(s)

Published by S. Karger AG, Basel

\section{Introduction}

Lung cancer is the leading cause of cancer-related deaths in men over40 years old and women over 60 years old around the world [1]. It is estimated that about 1.8 million new lung cancer cases and 1.6 million lung cancer deaths occurred worldwide in 2012, which accounted for about $19 \%$ of all cancer deaths $[2,3]$. Non-small cell lung cancer (NSCLC) accounts for more than $85 \%$ of all lung cancers, and about $60 \%$ of NSCLC patients present with advanced-stage disease at the time of diagnosis [4]. Chemotherapy for NSCLC is unsatisfactory due to drug resistance and adverse effects and contributes little to survival [5]. For example, tumor cells that survive apoptosis induced by the first-line anti-cancer drug paclitaxel (PTX) may become more drug-resistant [6, 7].

Caffeic acid (3, 4-dihydroxycinnamic acid, CA) is a natural phenolic acid present in many plants, fruits, vegetables, and teas. CA has been well-studied for its bioactive activities such as anti-oxidative and anti-inflammatory properties in many diseases. Treatment with $\mathrm{CA}$ has been proved to attenuate stress-induced insulin resistance by reducing inflammation [8]. CA can repress interleukin 6 (IL-6) and tumor necrosis factor $\alpha$ to alleviate inflammation responses by blocking the phosphorylation of І $\kappa \mathrm{B}$ and IкBkinase in rheumatoid arthritis-derived fibroblast-like synoviocytes [9]. CA acts as an antioxidant through an iron chelating mechanism to prevent the formation of free hydroxyl radicals and inhibit Fentoninduced oxidative damage [10]. CA can also inhibit oxidative stress mediated by exposure to UVB and DNA damage in human lymphocytes [11]. It has also been reported to have immunomodulatory and anti-cancer functions in human metastatic cervical carcinoma, ovarian carcinoma, and fibrosarcoma [12-16].

To determine the potential therapeutic efficacy and underlying mechanisms of CA in combination with PTX for the treatment of NSCLC, we used both H1299 cells and a xenograft mouse model in this study because a previous study had shown the protective effect of CA on PTX-induced cell death in NSCLC A549 cells through the NF- $\kappa B$ signaling pathway [17]. It was found in the previous study that high-dose CA $(600 \mu \mathrm{M})$ significantly induces apoptosis in A549 and H1299 cells and plays a potential role in modulating and enhancing PTX-induced apoptosis of NSCLC cells both in vivo and in vitro through the MAPK pathway.

\section{Materials and Methods}

\section{Cell culture and reagents}

Human bronchial epithelial cells (Beas-2b) and NSCLC H1299 cells were purchased from the Institute of Biochemistry and Cell Biology of the Chinese Academy of Sciences. Cells were cultured in DMEM supplemented with $10 \%$ fetal bovine serum (FBS), $100 \mathrm{U} / \mathrm{mL}$ penicillin, and $100 \mu \mathrm{g} / \mathrm{mL}$ streptomycin under standard culture conditions $\left(5 \% \mathrm{CO}_{2}\right.$ at $\left.37^{\circ} \mathrm{C}\right)$. FITC-Annexin $\mathrm{V} /$ propidium iodide (PI) apoptosis detection kits and Matrigel were purchased from BD Biosciences (Franklin Lakes, NJ). The Caspase-Gloß 3/7 and Caspase-Glo® 9 Assay System were purchased from Promega Corporation (Madison, WI). Caffeic acid (3, 4-dihydroxycinnamic acid, CA) and dimethylsulfoxide (DMSO) were purchased from Sigma-Aldrich (St Louis, MO). CA was dissolved in DMSO and the final dose of DMSO for all treatments was consistently $<0.1 \%$. All antibodies used in this study were purchased from Cell Signaling Technology (Danvers, MA). 


\section{Cellular Physiology Cell Physiol Biochem 2018;48:1433-1442 and Biochemistry Published online: July 31, $2018 \quad \begin{aligned} & \text { DOI: 10.1159/000492253 } 2018 \text { The Author(s). Published by S. Karger AG, Basel } \\ & \text { www.karger.com/cpb }\end{aligned}$ \\ Min et al.: Anticancer Activity of Caffeic Acid with Paclitaxel in H1299 Cells}

\section{Cell viability assay}

The cytotoxicity of CA and PTX in cells was assessed by MTT by measuring the metabolic activities of viable cells [18]. Cells were cultured in 96-well plates $\left(1 \times 10^{4} /\right.$ well, $\left.100 \mu \mathrm{L}\right)$ before treatment. After treatment with CA and PTX for $24 \mathrm{~h}$, the medium was removed, MTT $(100 \mu \mathrm{L})$ was added to each well $(0.5 \mathrm{mg} / \mathrm{mL})$,and the cells were incubated for another $4 \mathrm{~h}$. DMSO $(100 \mu \mathrm{L})$ was added to dissolve the solid formazan and the absorbance was measured with a microplate reader (Thermo Fisher Scientific, Waltham, MA) at $570 \mathrm{~nm}$.

\section{Caspase -3 and -9 activity assay}

Cells were plated in 96 -well plates at $1 \times 10^{4}$ cells per well and cultured in complete medium overnight. Cells were then treated with CA and PTX. Caspase- 3 and caspase- 9 activities were measured by adding $50 \mu \mathrm{L}$ Caspase-Glo ${ }^{3} 3 / 7$ or Caspase-Glo $\circledast$ 9after a 2 -h incubation at $37^{\circ} \mathrm{C}$ as previously reported [19], and luminescence was detected using a microplate reader (PerkinElmer Inc., Waltham, MA). Caspase-3 and caspase-9 activities were expressed as fold increases with respect to the DMSO control.

\section{Cell cycle analysis}

Cells were harvested after treatment and fixed with $70 \%$ ethanol at $4^{\circ} \mathrm{C}$ for $30 \mathrm{~min}$. Cells were washed twice with phosphate-buffered saline (PBS), re-suspended in PI solution $(50 \mathrm{mg} / \mathrm{mL}$ containing ribonuclease A [50 ng/mL]) at room temperature, and incubated for another 30 min in the dark. The distribution of cells with different DNA content was analyzed with Aria II flow cytometer (BD Biosciences).

\section{Annexin V/PI double staining}

H1299 cells were seeded into 6-well plates and incubated with different doses of CA and PTX for 24-h. Cells were harvested after treatment, washed twice with cold PBS, re-suspended in $1 \times$ binding buffer, and then stained with $5 \mu \mathrm{L}$ of Annexin $\mathrm{V}$ and $5 \mu \mathrm{L}$ of PI solution at room temperature in the dark. After a 15-min incubation, $400 \mu \mathrm{L} 1 \times$ binding buffer was added and the cells were analyzed by flow cytometry (Calibur, BD Bioscience).

\section{Western blot assay}

H1299 cells were seeded into 6-well plates and incubated with DMSO control and different concentrations of CA and PTX for 24h. Proteins were extracted in RIPA buffer and immunoblotting analysis was performed. Briefly, protein samples were subjected to sodium dodecyl sulfate polyacrylamide gel electrophoresis and transferred to polyvinylidene fluoride membranes. The membrane was blocked with $5 \%$ bovine serum albumin in TBST for $2 \mathrm{~h}$ at room temperature and incubated with primary antibody solution in $4^{\circ} \mathrm{C}$ overnight. After washing, the HRP-conjugated secondary antibody was incubated with the membrane and Tris-buffered saline with Tween 20 (TBST) at room temperature for another $1 \mathrm{~h}$. After washing three times, the secondary antibody was detected using ECL Plus and the band was detected using anenhanced chemiluminescence kit.

\section{Animals and xenografts}

Female nude mice aged 5 weeks were acclimated for 7 days before use. Xenograft models were established by subcutaneous injections of $\mathrm{H} 1299$ cells $\left(5 \times 10^{6}\right)$ suspended in Matrigel, and the behavior and growth of tumors among the mice were observed daily. Mice bearing evident tumors were chosen and divided into four groups: a PBS group, a PTX $(10 \mathrm{mg} / \mathrm{kg})$ group, a CA $(20 \mathrm{mg} / \mathrm{kg})$ group, and a CA $(20 \mathrm{mg} /$ $\mathrm{kg})+$ PTX $(10 \mathrm{mg} / \mathrm{kg})$ group. CA and PTX were dissolved in PBS for intraperitoneal administration to the mice every two days for two weeks. Tumor size was measured with calipers, and the tumor volume was calculated as $\mathrm{V}=1 / 2 \times\left(\right.$ length $\times$ width $\left.^{2}\right)$. All animal procedures were performed following the protocol approved by the Institutional Animal Care Committee of Shanghai Institute of Biochemistry and Cell Biology.

\section{Immunohistochemistry}

After treatment, the tumors were fixed with $4 \%$ formaldehyde solution, dehydrated, paraffin embedded, and cut into $10-\mu \mathrm{m}$ sections. Immunohistochemistry (IHC) was performed using primary rabbit anti-proliferating cell nuclear antigen (anti-PCNA), and phosphor-c-Jun NH2-terminal protein kinase (JNK) and phosphor-extracellular signal regulated kinase (ERK) antibodies. 


\section{Cellular Physiology Cell Physiol Biochem 2018;48:1433-1442 \begin{tabular}{l|l} 
DOI: 10.1159/000492253 & O 2018 The Author(s). Published by S. Karger AG, Basel \\
www.karger.com/cpb
\end{tabular} \\ Min et al.: Anticancer Activity of Caffeic Acid with Paclitaxel in H1299 Cells}

Statistical analysis

All quantitative data are expressed as the mean \pm SD as indicated. In all experiments, the Student's t test or one-way analysis of variance was used for statistical analysis using GraphPad Prism software (GraphPad Software Inc., La Jolla, CA). A P-value of $<0.05$ was considered a statistically significant result.

\section{Results}

The cytotoxic effects of CA alone or CA+PTX on H1299 cells

The chemical structures of CA and PTX are shown in Fig. 1A. The cytotoxic effects of CA on H1299 and Beas-2b cells were compared and analyzed. The results of 24-h treatments showed that CA was more cytotoxic in H1299 cells than in normal human Beas-2b cells (Fig. 1B). In addition, the cytotoxic effect of CA on H1299 cells increased in a time-dependent manner as observed at $6 \mathrm{~h}, 12 \mathrm{~h}, 24 \mathrm{~h}$, and 48h (Fig. 1C). To evaluate the synergistic effect of CA and PTX, H1299 cells were subjected to CA+PTX treatment. Compared with PTX treatment alone, $100 \mu \mathrm{M}$ CA significantly enhanced the PTX-induced inhibitory effect on the proliferation of H1299 cells (Fig. 1D), demonstrating that CA had a synergistic effect on PTXinduced anti-proliferation in H1299 cells.

Fig. 1. The cytotoxic effect of CA alone or CA+PTX on H1299 cells (A) Structure of CA and PTX. (B) Viability analysis of H1299 and Beas-2b cells incubated in the indicated dose of CA for 24-h, as assayed by MTT. (C) Viability of H1299 cells incubated in 50, 200 and $600 \mu \mathrm{M}$ of concentrations of CA for 0, 6, 12, 24 and 48-h. (D) Combined use of CA and PTX significantly inhibited H1299 cell viability compared with PTX alone. Each bar represents the mean $\pm S D, n=3$. ${ }^{* *} \mathrm{p}<0.005$, $* * * \mathrm{p}<0.001$.

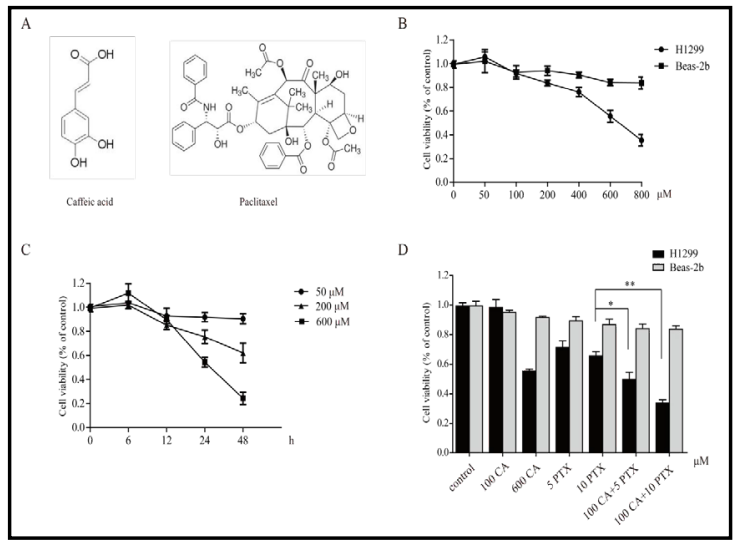

Fig. 2. CA induces cell apoptosis in H1299 cells. (A) H1299 cells were incubated with CA for $24 \mathrm{~h}$, harvested, and then subjected to quantitative analysis of cell apoptosis by Annexin V and PI double-stained flow cytometry. (B) The number of apoptotic cells accounts for the total cells of each group after 24-h treatment. Data are expressed as mean $\pm \mathrm{SD}, \mathrm{n}=3,{ }^{* *} \mathrm{P}<0.005,{ }^{* *} \mathrm{P}<0.001$.

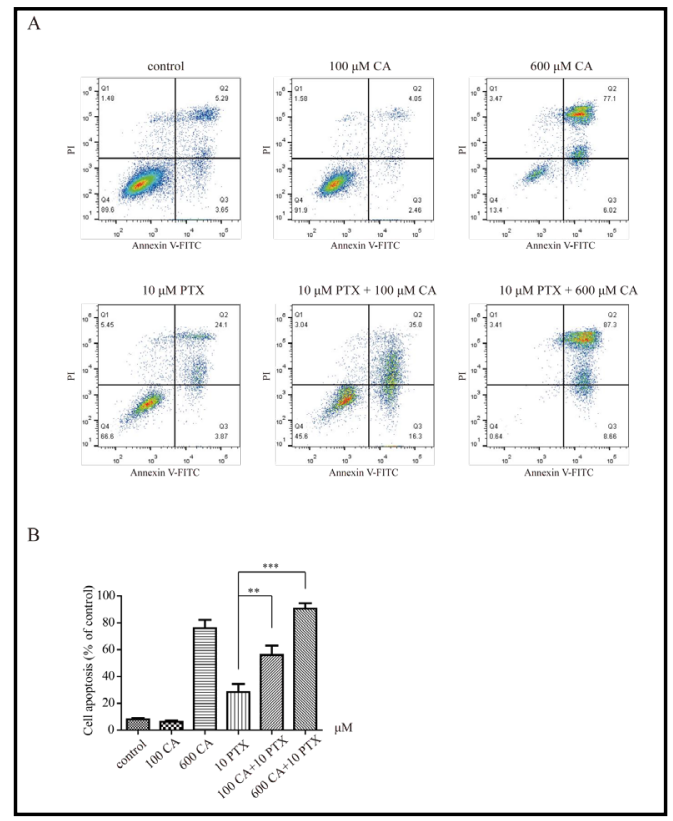




\section{Cellular Physiology Cell Physiol Biochem 2018;48:1433-1442

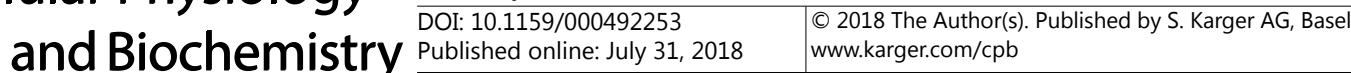 Min et al.: Anticancer Activity of Caffeic Acid with Paclitaxel in H1299 Cells}

CA induces apoptosis in $\mathrm{H1299}$ cells

Annexin V/PI apoptosis analysis showed that CA induced significant apoptosis in H1299 cells, especially when the dose was increased to over $500 \mu \mathrm{M}$. After $\mathrm{CA}+\mathrm{PTX}$ combined treatment for $24 \mathrm{~h}$, the percentage of apoptotic cells was increased significantly: $6.5 \%$ at $100 \mu \mathrm{M} \mathrm{CA}, 83 \%$ at 600 $\mu \mathrm{M}$ CA, $27.9 \%$ at $10 \mu \mathrm{M}$ PTX, and $96 \%$ at 10 $\mu \mathrm{M}$ PTX $+600 \mu \mathrm{M}$ CA(compared with $8.9 \%$ in the control group; Fig. 2). These results suggest that CA not only induced apoptosis of H1299 cells in a dose-dependent manner but also exhibited a strong synergistic effect when combined with PTX.

CA induces sub-G1 cell cycle arrest in H1299 cells

Flow cytometric analysis showed that CA treatment increased the population of cells in sub-G1 phase in H1299 cells and reduced the population of cells in G1 and G2/M phases (Fig. 3), suggesting that CA induced sub-G1 cell cycle arrest in H1299 cells. On the other hand, compared with PTX treatment alone, CA+PTX treatment induced G1 cell cycle arrest and reduced the number of cells in G2/M phase in H1299 cells.

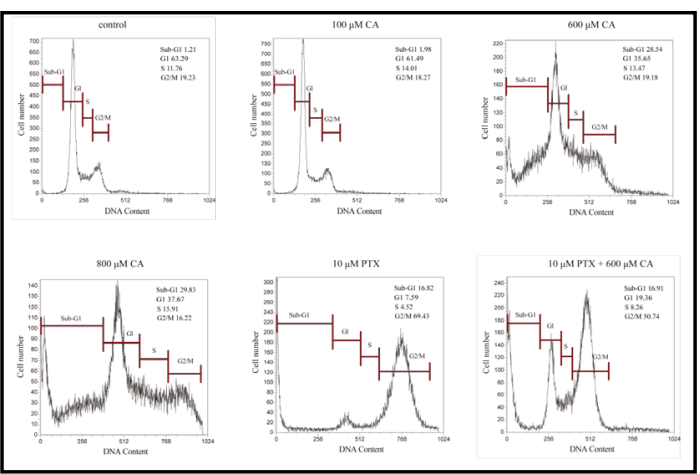

Fig. 3. CA induces sub-G1 cell cycle arrest in H1299 cells. H1299 cells were incubated with indicated dose of CA and PTX for $24 \mathrm{~h}$, stained with PI and analyzed for DNA content by flow cytometry.

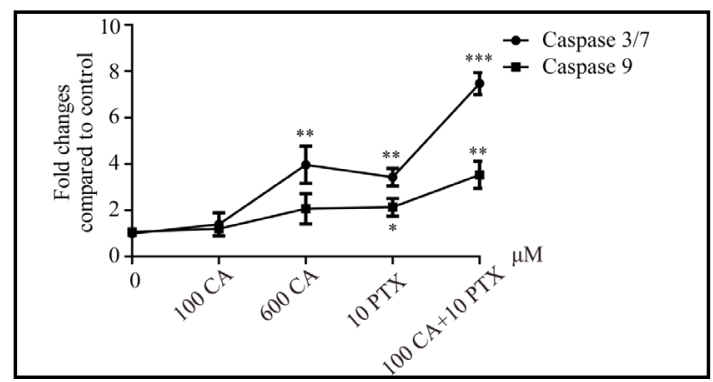

Fig. 4. Dose course of fold changes of caspase 3/7 and caspase 9 activity compared to control for H1299 cells treated with CA and PTX for 24-h. ${ }^{*} \mathrm{P}<0.05,{ }^{* *} \mathrm{P}<0.005,{ }^{* * *} \mathrm{P}<0.001$.

CAinduces activation of caspase-3 and caspase-9 in H1299 cells

Caspase- 3 and caspase- 9 activities assays were performed by Caspase-Glo® 3/7and Caspase-Glo® 9 assay systems. As shown in Fig. 4, caspase-3 activity was elevated by 4.0-foldin cells treated with $600 \mu \mathrm{M} \mathrm{CA}$, and 7.3-fold in cells treated with CA+PTX, while caspase- 9 activity was elevated by 2.2 -foldin cells treated with $600 \mu \mathrm{M} \mathrm{CA}$, and 3.1-fold in cells treated with CA+PTX. The results imply that a high dose of CA can induce the activation of caspase, and activation of the caspase-involved apoptotic pathway is one of the major mechanisms underlying the synergistic effect mediated by CA on PTX-treated H1299 cells.

CA induces apoptosis in $H 1299$ cells by regulating the expression of pro- and anti-apoptotic genes

To elucidate whether the regulation of BCL-2 family proteins was involved in CA-induced apoptosis, we further studied the expression profiles of pro-apoptotic proteins (cleavedPARP, Bid and Bax) and anti-apoptotic proteins (Bcl-2 and Bcl-xL) in H1299 cells treated with CA alone or CA+PTX for 24h. As shown in Fig. 5A, cleaved-PARP, Bax, and Bid were increased in a dose-dependent manner and CA and PTX combined reduced the expression levels of these proteins. On the contrary, the expression levels of both Bcl-2 and Bcl-xL in H1299 cells were reduced when they were incubated with different concentrations of CA+PTX. The expression levels of Bcl-2 and Bcl-xl in $\mathrm{H} 1299$ cells decreased by 4- to 6-fold after treatment with $600 \mu \mathrm{M} C A+10 \mu \mathrm{M}$ PTX compared with the control, respectively. These changes in the expression of pro- and anti-apoptotic genes suggested that CA alone and CA+PTX induced apoptosis inH1299 cells by activating genes involved in the intrinsic apoptotic pathway.

Knowing that MAPK signaling pathway plays an important role in chemotherapeutic 


\section{Cellular Physiology Cell Physiol Biochem 2018;48:1433-1442 \begin{tabular}{l|l} 
DOI: 10.1159/000492253 & $\begin{array}{l}\text { O } 2018 \text { The Author(s). Published by S. Karger AG, Basel } \\
\text { www.karger.com/cpb }\end{array}$
\end{tabular}

Fig. 5. CA induces apoptosis of H1299 cells by regulating the expression of pro- and anti-apoptotic genes. (A) H1299 cells were treated with CA or PTX for 24-h and subjected to western blotting with antibodies against Bax, Bid, cleaved-PARP, Bcl$\mathrm{xL}$ and Bcl-2. (B) H1299 cells were treated with different dose of CA or PTX and western blotting were applied for analysis of phosphorylation of ERK, JNK and p38. Phosphorylation of ERK and JNK were signifcantly elevated with CA and PTX.

Fig. 6. CA treatment retards the growth of H1299 xenografts in nude mice. (A) Volume of tumors in mice treated with PBS, CA, and PTX, alone or in combination. (B) After 10 days, the average tumor volume exceeded $50 \mathrm{~mm}^{3}$. The mice were then separated into four groups and treated with different dose of CA and PTX. Tumor volume of mice carrying xenografts were measured every three days. (C-F) Serum concentrations of various biochemical indicators were measured in the blood after the end of treatment. Blood biochemical analysis indicated there was no significant change in serum ALT, AST, Creatinine or BUN. ALT, alanine aminotransferase; AST, aspartate aminotransferase; BUN, blood urea nitrogen ${ }^{*} \mathrm{P}<0.05,{ }^{* *} \mathrm{P}<0.005,{ }^{* * *} \mathrm{P}<0.001$.

drugs by regulating apoptosis in cancer cells [20], we subsequently explored whether the MAPK pathway was involved in CA-induced apoptotic progress by examining the activation status of ERK1/2, P38mapk,and JNK. As shown in Fig. 5B, CA increased the phosphorylated form of ERK1/2 and JNK of H1299 cells, especially in the $600 \mu \mathrm{M}$ group, indicating that the MAPK signaling pathway was activated in H1299 cells. We also noticed that the phosphorylation levels of both ERK1/2 and JNK were substantially heightened with combined CA and PTX treatment compared to either CA or PTX alone; however, the phosphorylated form of p38 was unchanged. These results showed that ERK1/2 and JNK may play more important roles than p38 in the CAinduced synergistic effect on PTX-treated H1299 cells.

\section{CA treatment retards the growth of $H 1299$ xenografts in nude mice}

To further evaluate the tumor-suppressing effect of CA in vivo, a tumorigenicity model of H1299 cells in nude mice was established. Twenty-four mice were randomly allocated into four groups of equal size. As shown in Fig. 6A, either CA or PTX treatment alone inhibited the growth of xenograft tumors. Intraperitoneal administration of CA $(20 \mathrm{mg} /$ $\mathrm{kg}$ ) for three weeks reduced the tumor volume by $55 \%$, and this figure increased to $80 \%$ 


\section{Cellular Physiology Cell Physiol Biochem 2018;48:1433-1442 \begin{tabular}{l|l} 
DOI: 10.1159/000492253 & $\begin{array}{l}\text { O 2018 The Author(s). Published by S. Karger AG, Basel } \\
\text { www.karger.com/cpb }\end{array}$
\end{tabular} Min et al.: Anticancer Activity of Caffeic Acid with Paclitaxel in H1299 Cells}

when $20 \mathrm{mg} / \mathrm{kg}$ CA and $10 \mathrm{mg} / \mathrm{kg}$ PTX were administered concomitantly. These results suggest that CA treatment retarded the growth of H1299 xenografts, and the combined CA+PTX treatment exerted an even stronger anti-tumor effect on H1299 cells in vivo. Furthermore, there were no significant differences in body weight (Table 1), blood urea nitrogen (BUN), serum alanine transaminase (ALT), aspartate transaminase (AST), or creatinine (Cr) between mice treated with CA alone, PTX alone, or CA+PTX (Fig. 6), suggesting that neither renal toxicity nor hepatotoxicity was induced by the indicated doses of CA or

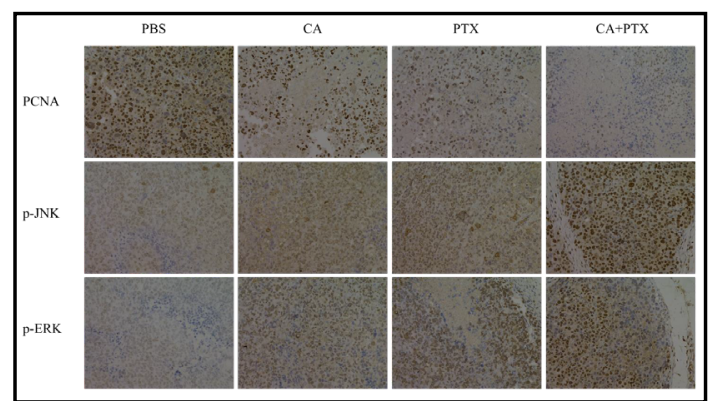

Fig. 7. Effects of CA and PTX on apoptosis in the xenograft model. Tumors from mice treated with CA and PTX were examined by PCNA, p-ERK and p-JNK immunohistochemistry. PTX under in vivo conditions.

Proliferating cell nuclear antigen (PCNA) is a proliferation marker required for DNA replication and cell-cycle progression [21]. As shown in Fig. 7, the IHC positive expression of PCNA was remarkably decreased after CA or PTX treatment, especially when the treatments were combined. We also found that the expression levels of p-JNK and p-ERK were increased significantly in the CA+PTX group compared with the control group, which is consistent with the results of western blot in H1299 cells. These results implied that tumor cell proliferation was reduced significantly after combined treatment with CA+PTX as indicated by PCNA and this correlated negatively with phosphor-JNK and phosphor-ERK expression.

\section{Discussion}

Ample research-based evidence has demonstrated that coffee consumption is closely related to a decreased risk of developing malignant tumors including oral and pharyngeal cancer, liver cancer, endometrial cancer, and colorectal cancer [22-25]. CA is the major phenolic compound in coffee and is one of the most abundant phenolic acids. It is commonly found in various foods such as apples, blueberries, and especially in coffee [10]. Studies have shown that CA has various pharmacological activities, including anti-inflammatory, antioxidant, and immunomodulatory activities [7-9]. CA also exhibits an anti-cancer effect against human cervical carcinoma, head and neck squamous carcinoma, colon cancer, and renal carcinoma $[12-14,26]$. A previous study showed that CA promoted NSCLC A549 cell proliferation and enhanced PTX-induced proliferation inA549 cells [17], suggesting that it has the potential to facilitate A549 growth through the p53 pathway and enhance the protective effect of PTX. However, the in vivo and in vitro effects on p53 deficiency cell line H1299 and the molecular mechanisms remain unclear. We found that CA+PTX produced a synergistic anticancer effect in NSCLC H1299 cancer cells by inducing cell apoptosis, probably via the MAPK pathway.

In this study, we tested the effect of CA on PTX-treated NSCLC H1299 cells using MTT and Annexin V-FITC/PI double staining assays and found that CA inhibited the growth and proliferation of H1299 cells in a dose-dependent manner, which is consistent with studies in other cancer cells [12-15]. However, we found that the effective concentration of CA in H1299 cells should be no lower than $500 \mu \mathrm{M}$. Although this dosage is higher than that used in other cancer cell lines, it showed no significant toxic effects on normal Beas-2b cells, implying that this high dose of CA can be used safely. In addition, low-dose CA $(100 \mu \mathrm{M})$ enhanced the PTX-induced anti-proliferation in H1299 cells. On the other hand, CA alone induced significant apoptosis inH1299 cells and also substantially increased PTX-induced apoptosis in H1299 cells, as shown by Annexin V/PI double staining. Flow cytometric analysis showed that H1299 cells were arrested in sub-G1 phase under CA treatment, and the combined use 


\section{Cellular Physiology Cell Physiol Biochem 2018;48:1433-1442

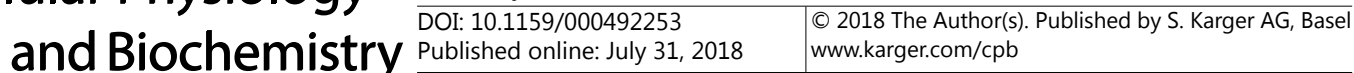 \\ Min et al.: Anticancer Activity of Caffeic Acid with Paclitaxel in H1299 Cells}

of the two chemicals effectively reduced tumor growth in H1299 xenograft mice without obvious toxicity in the animals. Based on the antitumor activity profiles of combined CA+PTX treatment both in vivo and in vitro, we believe that CA has a strong anti-cancer effect in NSCLC H1299 cells and possesses a synergistic value when used in combination with PTX in H1299 cells.

The Bcl-2 family is known as a caretaker of cell fate [27] and consists of members that either promote apoptosis (Bax and Bid) or inhibit it (Bcl-2 and Bcl-xL) [28-30]. In the present work, we showed that Bax, Bid, and cleaved PARP protein were increased and both Bcl-2 and Bcl-xL expression were decreased in a dose-dependent manner after CA treatment. These findings are consistent with the results of the cell apoptosis assay. Previous studies [3133] suggested that MAPKs can be induced by various compounds and are involved in cell death in NSCLC cells. The MAPK family includes three kinase members including JNK/stress activated protein kinases, P38mapk, and ERK [34]. These previous findings tempted us to ask whether the tumor-suppressing effect of CA relied on the presence of the MAPK signaling system in H1299 cells. To answer this question, we further investigated the activation of the MAPK family proteins in CA-treated $\mathrm{H} 1299$ cells. The results showed that MAPKs including phosphorylation of ERK1/2, P38mapk, and JNK1/2 were activated in CA-treated H1299 cells in a dose-dependent manner, implying that activation of the MAPK pathway was involved in the CA-induced apoptosis in H1299 cells. Further experiments with pre-treatment of MAPK inhibitors in NSCLC H1299 cells are needed.

Taken together, our study clearly demonstrated that treatment with a high-concentration of CA alone or low-dose CA plus PTX had a strong inhibitory effect on the growth of NSCLC H1299 cells and induced apoptosis both in vivo and in vitro, probably through the MAPK signaling pathway and caspases. Our findings suggest that CA is a promising compound that should be further investigated in combination with more anti-cancer chemotherapy drugs for the treatment of NSCLC.

\section{Acknowledgements}

This work was supported by the National Natural Science Foundation of China (No. 81670299 to W. Z. and 81700296 to Y. L.), Shanghai Leading Talent Project (No.44 to W. Z.), Shanghai Municipal Commission of Health and Family Planning (N0.201640172 to Y. Q.).

\section{Disclosure Statement}

All authors declare that they have no conflict of interests.

\section{References}

1 Siegel R, Ma J, Zou Z, Jemal A: Cancer statistics, 2014. CA Cancer J Clin 2014;64:9-29.

-2 Ferlay J, Soerjomataram I, Dikshit R, Eser S, Mathers C, Rebelo M, Parkin DM, Forman D, Bray F: Cancer incidence and mortality worldwide: sources, methods and major patterns in GLOBOCAN 2012. Int J Cancer 2015;136:E359-386.

3 Travis WD, Brambilla E, Nicholson AG, Yatabe Y, Austin JHM, Beasley MB, Chirieac LR, Dacic S, Duhig E, Flieder DB, Geisinger K, Hirsch FR, Ishikawa Y, Kerr KM, Noguchi M, Pelosi G, Powell CA, Tsao MS, Wistuba I, Panel WHO: The 2015 World Health Organization Classification of Lung Tumors: Impact of Genetic, Clinical and Radiologic Advances Since the 2004 Classification. J Thorac Oncol 2015;10:1243-1260.

4 Jemal A, Bray F, Center MM, Ferlay J, Ward E, Forman D: Global cancer statistics. CA Cancer J Clin 2011;61:6990.

5 Scheff RJ, Schneider BJ: Non-small-cell lung cancer: treatment of late stage disease: chemotherapeutics and new frontiers. Semin Intervent Radiol 2013;30:191-198. 


\section{Cellular Physiology Cell Physiol Biochem 2018;48:1433-1442

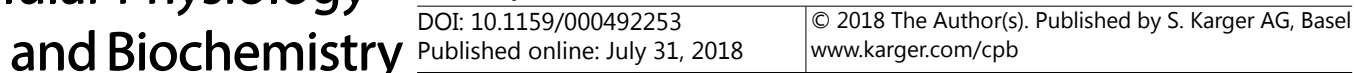 \\ Min et al: Anticancer Activity of Caffeic Acid with Paclitaxel in H1299 Cells}

6 Tabuchi Y, Matsuoka J, Gunduz M, Imada T, Ono R, Ito M, Motoki T, Yamatsuji T, Shirakawa Y, Takaoka M, Haisa M, Tanaka N, Kurebayashi J, Jordan VC, Naomoto Y: Resistance to paclitaxel therapy is related with Bcl-2 expression through an estrogen receptor mediated pathway in breast cancer. Int J Oncol 2009;34:313-319.

-7 Chen X, Sun X, Guan J, Gai J, Xing J, Fu L, Liu S, Shen F, Chen K, Li W, Han L, Li Q: Rsf-1 Influences the Sensitivity of Non-Small Cell Lung Cancer to Paclitaxel by Regulating NF-kappaB Pathway and Its Downstream Proteins. Cell Physiol Biochem 2017;44:2322-2336.

-8 Choudhary S, Mourya A, Ahuja S, Sah SP, Kumar A: Plausible anti-inflammatory mechanism of resveratrol and caffeic acid against chronic stress-induced insulin resistance in mice. Inflammopharmacology 2016;24:347361.

-9 Wang W, Sun W, Jin L: Caffeic acid alleviates inflammatory response in rheumatoid arthritis fibroblastlike synoviocytes by inhibiting phosphorylation of IkappaB kinase alpha/beta and IkappaBalpha. Int Immunopharmacol 2017;48:61-66.

10 Genaro-Mattos TC, Mauricio AQ, Rettori D, Alonso A, Hermes-Lima M: Antioxidant Activity of Caffeic Acid against Iron-Induced Free Radical Generation--A Chemical Approach. PLoS One 2015;10:e0129963.

11 Prasad NR, Jeyanthimala K, Ramachandran S: Caffeic acid modulates ultraviolet radiation-B induced oxidative damage in human blood lymphocytes. J Photochem Photobiol B 2009;95:196-203.

12 Tyszka-Czochara M, Konieczny P, Majka M: Caffeic Acid Expands Anti-Tumor Effect of Metformin in Human Metastatic Cervical Carcinoma HTB-34 Cells: Implications of AMPK Activation and Impairment of Fatty Acids De Novo Biosynthesis. Int J Mol Sci 2017;18:462-471.

13 Sirota R, Gibson D, Kohen R: The timing of caffeic acid treatment with cisplatin determines sensitization or resistance of ovarian carcinoma cell lines. Redox Biol 2017;11:170-175.

14 Nasr Bouzaiene N, Kilani Jaziri S, Kovacic H, Chekir-Ghedira L, Ghedira K, Luis J: The effects of caffeic, coumaric and ferulic acids on proliferation, superoxide production, adhesion and migration of human tumor cells in vitro. Eur J Pharmacol 2015;766:99-105.

15 Kilani-Jaziri S, Mokdad-Bzeouich I, Krifa M, Nasr N, Ghedira K, Chekir-Ghedira L: Immunomodulatory and cellular anti-oxidant activities of caffeic, ferulic, and p-coumaric phenolic acids: a structure-activity relationship study. Drug Chem Toxicol 2017;40:416-424.

16 Rajendra Prasad N, Karthikeyan A, Karthikeyan S, Reddy BV: Inhibitory effect of caffeic acid on cancer cell proliferation by oxidative mechanism in human HT-1080 fibrosarcoma cell line. Mol Cell Biochem 2011;349:11-19.

17 Lin CL, Chen RF, Chen JY, Chu YC, Wang HM, Chou HL, Chang WC, Fong Y, Chang WT, Wu CY, Chiu CC: Protective effect of caffeic acid on paclitaxel induced anti-proliferation and apoptosis of lung cancer cells involves NFkappaB pathway. Int J Mol Sci 2012;13:6236-6245.

18 Zhang SH, Li ZY, Liu ZJ, Miao GY, Liu BG: MicroRNA15b regulates apoptosis of cutaneous squamous cell carcinoma SCL-1 cell line: a mechanism study. Eur Rev Med Pharmacol Sci 2017;21:227-233.

19 Leong KH, Mahdzir MA, Din MF, Awang K, Tanaka Y, Kulkeaw K, Ishitani T, Sugiyama D: Induction of intrinsic apoptosis in leukaemia stem cells and in vivo zebrafish model by betulonic acid isolated from Walsura pinnata Hassk (Meliaceae). Phytomedicine 2017;26:11-21.

20 Jia H, Dilger P, Bird C, Wadhwa M: IL-27 Promotes Proliferation of Human Leukemic Cell Lines Through the MAPK/ERK Signaling Pathway and Suppresses Sensitivity to Chemotherapeutic Drugs. J Interferon Cytokine Res 2016;36:302-316.

-21 Kato K, Kawashiri S, Yoshizawa K, Kitahara H, Okamune A, Sugiura S, Noguchi N, Yamamoto E. Expression form of p53 and PCNA at the invasive front in oral squamous cell carcinoma: correlation with clinicopathological features and prognosis. J Oral Pathol Med 2011;40:693-698.

22 Turati F, Galeone C, La Vecchia C, Garavello W, Tavani A: Coffee and cancers of the upper digestive and respiratory tracts: meta-analyses of observational studies. Ann Oncol 2011;22:536-544.

23 Bosetti C, Turati F, La Vecchia C: Hepatocellular carcinoma epidemiology. Best Pract Res Clin Gastroenterol 2014;28:753-770.

24 Je Y, Giovannucci E: Coffee consumption and risk of endometrial cancer: findings from a large up-to-date meta-analysis. Int J Cancer 2012;131:1700-1710.

25 Vitaglione P, Fogliano V, Pellegrini N: Coffee, colon function and colorectal cancer. Food Funct 2012;3:916922. 


\section{Cellular Physiology Cell Physiol Biochem 2018;48:1433-1442 \begin{tabular}{l|l} 
and Biochemistry & DOb: 10.1159/000492253 \\
\cline { 2 - 3 } abhed online: July 31, 2018 & $\begin{array}{l}\text { O 2018 The Author(s). Published by S. Karger AG, Basel } \\
\text { www.karger.com/cpb }\end{array}$
\end{tabular} \\ Min et al.: Anticancer Activity of Caffeic Acid with Paclitaxel in H1299 Cells}

26 Dziedzic A, Kubina R, Kabala-Dzik A, Tanasiewicz M: Induction of Cell Cycle Arrest and Apoptotic Response of Head and Neck Squamous Carcinoma Cells (Detroit 562) by Caffeic Acid and Caffeic Acid Phenethyl Ester Derivative. Evid Based Complement Alternat Med 2017;2017:1-10.

27 Martinou JC, Youle RJ: Mitochondria in apoptosis: Bcl-2 family members and mitochondrial dynamics. Dev Cell 2011;21:92-101.

-28 Zaltsman Y, Shachnai L, Yivgi-Ohana N, Schwarz M, Maryanovich M, Houtkooper RH, Vaz FM, De Leonardis F, Fiermonte G, Palmieri F, Gillissen B, Daniel PT, Jimenez E, Walsh S, Koehler CM, Roy SS, Walter L, Hajnoczky G, Gross A: MTCH2/MIMP is a major facilitator of tBID recruitment to mitochondria. Nat Cell Biol 2010;12:553562.

29 Edlich F, Banerjee S, Suzuki M, Cleland MM, Arnoult D, Wang C, Neutzner A, Tjandra N, Youle RJ: Bcl-x(L) retrotranslocates Bax from the mitochondria into the cytosol. Cell 2011;145:104-116.

30 Schellenberg B, Wang P, Keeble JA, Rodriguez-Enriquez R, Walker S, Owens TW, Foster F, Tanianis-Hughes J, Brennan K, Streuli CH, Gilmore AP: Bax exists in a dynamic equilibrium between the cytosol and mitochondria to control apoptotic priming. Mol Cell 2013;49:959-971.

-31 Min J, Huang K, Tang H, Ding X, Qi C, Qin X, Xu Z: Phloretin induces apoptosis of non-small cell lung carcinoma A549 cells via JNK1/2 and p38 MAPK pathways. Oncol Rep 2015;34:2871-2879.

32 Chao W, Deng JS, Li PY, Liang YC, Huang GJ: 3, 4-Dihydroxybenzalactone Suppresses Human Non-Small Cell Lung Carcinoma Cells Metastasis via Suppression of Epithelial to Mesenchymal Transition, ROS-Mediated PI3K/AKT/MAPK/MMP and NFkappaB Signaling Pathways. Molecules 2017;22:537-548.

-33 Tung CL, Jian YJ, Chen JC, Wang TJ, Chen WC, Zheng HY, Chang PY, Liao KS, Lin YW: Curcumin downregulates p38 MAPK-dependent X-ray repair cross-complement group 1 (XRCC1) expression to enhance cisplatininduced cytotoxicity in human lung cancer cells. Naunyn Schmiedebergs Arch Pharmacol 2016;389:657666.

34 Cargnello M, Roux PP: Activation and function of the MAPKs and their substrates, the MAPK-activated protein kinases. Microbiol Mol Biol Rev 2011;75:50-83. 